\title{
The Effects of Humic Acid Application on Soil and Foliar Iron Oxide Nanoparticle Sprays on Some Quantitative and Qualitative Traits of Snapdragon (Variety Montego Rose Bicolor)
}

\author{
Mohammad Aslanpour ${ }^{1}$; Mahmoud Shoor ${ }^{2}$; Safiyeh Zia'ei ${ }^{3}$ and Mohammad Moghaddam ${ }^{4}$ \\ ${ }^{1}$ Associate professor, horticultural sciences department, Raprin Ranie University, \\ sulaimany Kurdistan Branch, Iraq. \\ ${ }^{2}$ Associate professor, agriculture department, Ferdowsi University, Mashhad, Iran \\ ${ }^{3} \mathrm{MA}$ graduate, agricultural sciences, Mashhad University, Mashhad, Iran \\ ${ }^{4}$ Associate professor, agricultural sciences, Ferdowsi University, Mashhad, Iran \\ Email: Aslanpour.mohammad@gmail.com; Mobile: +98-914-3894348; Tel.: +98-9647510384174
}

\begin{abstract}
Snapdragon is an herbaceous annual plant with large diversities in color and shape and a long flowering period; it is a resistant and semi-resistant plant from scrophulariaceae family. It is used as either cut flower or garden plant. The use of fertilizers with no side effects is necessary for the nature. Humic acid has been named amongst the nature-friendly organic fertilizers. In the present study, the effects of on-soil humic acid application in four concentrations $(0 \mathrm{mg} / \mathrm{l}, 50 \mathrm{mg} / \mathrm{l}, 100 \mathrm{mg} / \mathrm{l}$ and $200 \mathrm{mg} / \mathrm{l})$ and foliar iron oxide nanoparticles' foliar sprays in four levels $(0 \mathrm{mg} / \mathrm{l}, 150 \mathrm{mg} / \mathrm{l}, 300 \mathrm{mg} / \mathrm{l}$ and $450 \mathrm{mg} / \mathrm{l})$ have been investigated on the quantitative and qualitative traits of snapdragon, Montego Rose Bicolor Variety. To do so, a factorial experiment within the format of complete randomized block design was carried out in three replications. The measured variables were plant height, number of florets, the emergence time of the first florets, wet and dry weights of the aerial organs and root, electrolyte leakage, total phenol, amount of soluble sugar, chlorophyll content and anthocyanin amount. Based on the results obtained from variance analysis, the mutual effect of humic acid and iron oxide nanoparticles was significant increase in the percentages of such traits as the length of the flower cluster, flower persistence, wet root weight, dry root weight, dry weight of the aerial organs, chlorophyll a, chlorophyll b, total chlorophyll, sugar content and electrolyte leakage in a $1 \%$ level. The effect of iron oxide nanoparticles alone was also significant increase in a $1 \%$ level in such traits as the wet weight of the aerial organs, total phenol content and anthocyanin amount but the plant height, number of ancillary branches, number of nodes, number of open florets, number of closed florets, the total number of florets and the time of the second series of flowering were not influenced by any of the applied treatments. The maximum amounts of the dry weight of the aerial organs $(0.032 \mathrm{~g})$, the amount of chlorophyll $b(16.91 \mathrm{mg} / \mathrm{g}$.wet weight) and sugar content $(0.76 \mathrm{mg} /$ g.wet weight) were observed in Fe300Hu50 treatment; the maximum amounts of phenol (2.88mg/g.wet weight) and flower persistence (95.66 days) were observed in Fe150Hu0 treatment and the highest rates of total chlorophyll $(30.78 \mathrm{mg} /$ g.wet weight), length of the flower cluster $(5.9 \mathrm{~cm})$ and the lowest electrolyte leakage (21.23\%) were seen in Fe300Hu100, Fe450Hu50 and Fe450Hu100 treatments.
\end{abstract}

Keywords: dry weight of the aerial organs, photosynthetic pigments, electrolyte leakage, nutrition

\section{Introduction:}

The population increase and expansion in the urban and industrial life not only causes decrease in the natural green spaces but it also brings about an increase in the pollutants and threatens the physical and psychological health of the human beings. Therefore, the expansion of the green spaces and the use of ornamental plants in parks and urban spaces are being increased for reducing the pollutions and enhancing the human health. Nowadays, besides satisfying the psychological and mental needs worldwide, the ornamental plants bring billions of dollars to the producing countries in the global markets and this has enticed a larger deal of attention in the countries to these plants (Ghasemi et al, 2013).

In Iran, the flowers and plants have been commonly used in designing green spaces since 3000 years ago but the commercial production of them dates back to 90 years ago. Foreign currency spent on ornamental plants is equivalent to one percent of production expenses and this is reflective of the very low cost of producing them in contrast to the other agricultural crops. 
At present, environment conservation and sustainable development achievement are amongst the primary and essential topics placed along with the other comprehensive economic, social and cultural plans atop of the programs implemented by various countries around the globe, Iran included. Thus, the experts in agricultural sciences and the other related sciences attempt to find proper substitutes for the chemical fertilizers through devising various methods thereby to gradually dispatch organic products to the markets in lieu of the current products. Organic farming (organic, natural and bio-agriculture) is a type of agriculture in the production and processing of its products no use is made of chemical fertilizers, hormones, transformations and genetic manipulations and all of the land strengthening, sowing, growing and harvesting stages are carried out using natural throughputs like bio-fertilizers, composts, useful insects, microorganisms and so forth (Nasirpour et al, 2014 and Ghorbani et al, 2010).

\section{Importance and Scattering of Snapdragon:}

Investigation of the References:

Snapdragon is a seasonal flower that is widely applied in green spaces due to its high diversity in shape and color and long flowering period alone or in combination with the other seasonal flowers. Moreover, the plant is very much resistant to harsh conditions like dry lands, limy soils and less vulnerable to diseases and pests; it can also be readily propagated through seeds and all of these characteristics add to the value and importance of this plant. Snapdragon can be divided in terms of height to three sets of short $(20 \mathrm{~cm})$, medium $(45 \mathrm{~cm})$ and tall $(65 \mathrm{~cm})$ (Ghasemi Ghahsareh, 2005).

Snapdragon is seen in simple forms, closed cup with kinds known as butterfly-shaped wherein the flower cup is open and possesses identical edges (Bailey, 1949). The flowers are produced in an array of colors from white and yellow to orange, red and purple to nearly black and it is not seen only in blue. Like gladiola, snapdragon has such characteristics as geotropism for which reason the cut flowers should be carried in a vertical position. In terms of flowering conditions, snapdragons are classified into four groups:

A) Winter type: it produces flowers under short-day conditions and a nocturnal temperature in a range from $7^{\circ} \mathrm{C}$ to $10^{\circ} \mathrm{C}$.

B) The type producing flowers during late winter and early spring: it produces flowers under short-day conditions (but not as short as the first group), intermediate light and nocturnal temperatures in a range from $10^{\circ} \mathrm{C}$ to $13^{\circ} \mathrm{C}$.

C) Spring type: it produces flowers during intermediate to long days and needs an intermediate to high light intensity and a nocturnal temperature in a range from $13^{\circ} \mathrm{C}$ to $16^{\circ} \mathrm{C}$.

D) Summer type: it produces flowers during long days and needs a high light intensity and nocturnal temperatures above $16^{\circ} \mathrm{C}$. The flowering season of this plant is very long and it usually bears flowers till late December and sometimes into January (Ghasemi et al, 2013). It produces flowers during entire fall and winter in tropical regions (Daneshvar, 1993). The plants start inflorescence since mid-May and it lasts for two months in the first stage. After the termination of the blossoming on the main stalk, it is cut from the point near the ancillary branches so that they might take its place. This way, inflorescence continues till late fall (Bailey, 1949).

\subsection{The Term "Nano" Conceptualized:}

In the world of science, "Nano" means one billionth. A Nano is one billionth of a meter. A nanometer only incorporates the length of ten atoms at each other's side. Nanotechnology essentially means a sort of technology in nanometer scale for achieving useful goals via manipulating and changing the structures. The normal rules of physics and chemistry cannot stay accountable in such a scale. Instead, such features of the materials as color, stability, conductance and reactivity can be variable between Nano- and Macro-scales (Chinamoto and Morogsabaputi, 2009).

\section{The Importance and Application Method of Micronutrient Fertilizers (Importance of Spraying Method):}

The daily increase in the price of the chemical fertilizers in world, the necessity for the productions to be costeffective, the contamination of the groundwater and destruction of the soil structure as a result of the unconscious and immethodical use of chemical fertilizers are the problems that have to be resolved by proper methods. In parallel, foliar nutrition (foliar spray) is a proper method for reducing the use of chemical fertilizers and preventing the environmental dangers to them especially during the present time that the policy of reducing the consumption of the chemicals and optimization of fertilizer applications have been frequently pointed out worldwide. Therefore, foliar nutrition is of a particular importance. It is by foliar nutrition that the nutrients can be quickly made available to the plants. In this method, the branches and leaves or fruits are directly provided with the required nutrients. In some of the cases, especially when such a phenomenon as antagonism renders the uptake of materials through roots disrupted and/or the addition of materials to the soil destroys the soil's living organisms, foliar nutrition becomes very much important (Malakuti and Tehrani, 2005). 
It has been reported that iron spraying is a more effective method in all of the agricultural plants for compensating the iron deficiency and it is deemed more acceptable than applying it to the soil (Mortodet et al, 1972). It has been asserted in a study of plant nourishment by less-consumed elements like zinc, manganese and iron that the foliar application of them can bring about more increase in the corn's performance than its application on soil and/or than seed treatment by them (Malakuti and Tehrani, 2005).

\section{Humic Acid:}

The humus ingredients of organic materials contain two important organic acids named humic acid and fulvic acid as components of humin (Sabzevari et al, 2009) that are different in terms of chemical structure and molecular size and they are extracted from various sources like soil, humus, peat, oxidized lignite and coal (Sabzevari et al, 2009 and Ghasemi et al, 2013). These two organic acids (humic acid and fulvic acid) account for $65 \%$ to $70 \%$ of the organic materials' ingredients (Nasirpour et al, 2014 and Mohammadi, 2013). Humic materials contain many organic and mineral ingredients like amine acids, peptides, phenols, aldehydes and nucleic acids that create complex and durable structures when bonded with various kinds of cations and nobody has ever been able to completely decompose humic materials (Mohammadi, 2013). Humic acids are complex macromolecules formed in soil during humification by chemical and bacterial phenomena in soil (Rashiditabar and Tawhidi, 2014). These substances are natural polymers containing $\mathrm{H}^{+}$sites for acidic functional groups like carboxyl benzoic acid and phenolcarboxylic acid (cation exchange loci) (Rahi et al, 2012). Humic acid features a molecular weight between 30000 daltons to 300000 daltons (Fatemi et al, 2011; Salehi et al, 2013 and Sabzevari et al (2009). The physiological essence of the humic substances' function is possibly that the humic substances satisfy the oxygen deficits in the plants hence improve the uptake in plants followed by an increase in their growth. The effects of humic acid can be divided into two sets: the direct effect that is exerted by a quasi-hormone compound and the indirect effect that is exerted through the absorption of nutritional elements by chelation and preserving the membrane's permeability (Chamani et al, 2012 and Salehi et al, 2010 and 2013). Humic acid also has a growth regulation attribute. Acid Humic's quasi-hormone property in the plants causes increases in the sprouting percentage and root elongation speed as well as acceleration of the branches' growth and elongation of the seedlings (Hosseini Darvishani and Chamani, 2013).

\section{Materials and Methods:}

\section{Experiment Implementation Location:}

To investigate the effects of on-soil application of humic acid and foliar spraying of iron oxide nanoparticles on some quantitative and qualitative traits of snapdragon (Montego Rose Bicolor), an experiment was designed and conducted in research greenhouses of Horticultural and Green Space Engineering Sciences Faculty of Ferdowsi University in Mashhad during 2017-2018.

\section{Study Design:}

The experiment was conducted in factorial form within the format of complete randomized block design in three replications and two fertilizer treatments each in four levels on a total of 48 flower pots. The experiment treatments were as listed below:

1) Iron oxide nanoparticles were sprayed in four levels of $0 \mathrm{mg} / 1,150 \mathrm{mg} / 1,300 \mathrm{mg} / 1$ and $450 \mathrm{mg} / 1$

2) Humic acid application on soil through dispersion in irrigation water in four levels of $0 \mathrm{mg} / \mathrm{l}, 50 \mathrm{mg} / \mathrm{l}$, $100 \mathrm{mg} / 1$ and $200 \mathrm{mg} / 1$

\section{Preparing Snapdragon Plantlets:}

F1 seeds of snapdragon were procured from Goldsmith Seeds Company and grown on culture trays containing cocopeat and perlite on $20^{\text {th }}$ of September, 2017 and transplanted on $15^{\text {th }}$ of November in the same year after sufficient growth of the root in four-leaf stage to the main pots.

\section{Cultivation Bed Preparation:}

The materials of the prepared bed were garden soil, humus and sand that had been mixed in a ratio of 1:2:1. The project included 48 pots, $30 \mathrm{~cm}$ in the mouth diameter and $50 \mathrm{~cm}$ in height.

\section{The Time to the Implementation of Fertilizer Treatments:}

Fertilization included three stages with the first one conducted when the plants were in 6- to 8-leaf stage; the second and the third rounds were carried out within 30-day intervals. Humic acid was applied in irrigation water and iron oxide nanoparticles' foliar spraying was simultaneously conducted on each flower pot.

Physiological traits and anthocyanin amount were measured; in order to determine the amount of anthocyanin, $0.1 \mathrm{~g}$ of the fresh petal tissues was completely milled in a porcelain mortar with $10 \mathrm{ml}$ of methanol acid (pure methanol and pure hydrochloric acid for a volumetric ratio of 1:99) and the extract was poured in a screw-cap test tube and stored in a dark refrigerator for 24 hours. Then, the supernatant was separated without shaking the solution and the overlying solution's absorption was measured in $512 \mathrm{~nm}$ by a spectrophotometer. The 
concentration was calculated using the following formula and by considering an extinction coefficient $(\varepsilon)$ of $33000 \mathrm{~cm} / \mathrm{mole}$.

$\mathrm{A}=\varepsilon b \mathrm{c}$

Where, A denotes absorption; $\mathrm{b}$ is the cell width and $\mathrm{c}$ is the concentration of the intended solution (Wagner, 1979).

\section{Total Phenol Measurement:}

At first, $100 \mathrm{mg}$ of the plant sample was extracted in $10 \mathrm{ml}$ of the methanol solvent and the obtained solution was

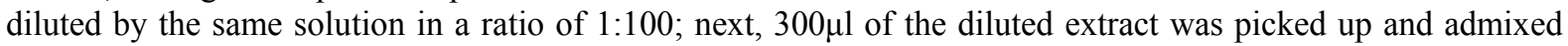
with $1.2 \mathrm{ml}$ of sodium carbonate $7.5 \%$ and $1.5 \mathrm{ml}$ of Folin-Ciocalteu's phenol reagent $10 \%$. Then, the samples were kept in darkness for 30 minutes and the absorption was read in $765 \mathrm{~nm}$. The standard diagram of this trait was drawn for gallic acid concentrations of $0 \mathrm{mg} / 1, \quad 3 \mathrm{mg} / \mathrm{l}, \quad 5 \mathrm{mg} / \mathrm{l}, \quad 8 \mathrm{mg} / 1, \quad 10 \mathrm{mg} / \mathrm{l}$ and $12 \mathrm{mg} / 1$ $(\mathrm{y}=0.0094 \mathrm{x}+0.0529)$.

\section{Measuring the Amount of Soluble Sugar:}

To prepare the extract, $500 \mathrm{mg}$ of the milled leaf sample was weighed and extract preparation was carried out by $5 \mathrm{ml}$ of methanol $95 \%$. Then, the extract was centrifuged for 15 minutes in $4500 \mathrm{rpm}$. Next, $100 \mu \mathrm{l}$ of the supernatant was admixed with $3 \mathrm{ml}$ of anthrone solution. The experiment tubes were subsequently placed in a $100^{\circ} \mathrm{C}$ hot water bath for 10 minutes following which the test tubes removed from hot water bath were allowed to cool down and the absorption was read in $625 \mathrm{~nm}$ by spectrophotometry. To make a standard solution, glucose was prepared for such concentrations as $0 \mu \mathrm{g}, 20 \mu \mathrm{g}, 40 \mu \mathrm{g}, 60 \mu \mathrm{g}, 80 \mu \mathrm{g}$ and $100 \mu \mathrm{g}$ and admixed with $3 \mathrm{ml}$ of anthrone. The rest of the stages were carried out as done for the previously made samples and the wavelength was read. The standard curve was drawn and the concentration of the sugar in the samples was attained according to the obtained equation (Carol et al, 1956) ( $y=113.08 x-8.8)$.

\section{Measuring the Chlorophyll Content:}

$200 \mathrm{mg}$ fresh leaves were separated from the completely developed leaves and put in porcelain mortar to be grinded and squashed. $10 \mathrm{ml}$ methanol $96 \%$ was added to the milled sample and the solution was stirred for a while and the obtained liquid was poured in falcon tubes that were centrifuged for $10 \mathrm{~m}$ in $2500 \mathrm{rpm}$. The overlying extract obtained from centrifuge was subsequently used for reading absorption wavelength. An amount of the centrifuged sample was placed inside a covet spectrophotometer and the samples' absorption rates were separately read in $663 \mathrm{~nm}$ for chlorophyll a and in $653 \mathrm{~nm}$ for chlorophyll $\mathrm{b}$. In the end, the following formulas were used for obtaining the amounts of chlorophyll $\mathrm{a}$ and $\mathrm{b}$ as well as total chlorophyll in milligram per gram of the sample's wet weight (Darreh et al, 1998).

Chlorophyll a $(\mathrm{CHLa})=15 / 65 \mathrm{~A} 666-7 / 340 \mathrm{~A} 653$

Chlorophyll b $(\mathrm{CHLb})=27 / 05 \mathrm{~A} 653-11 / 21 \mathrm{~A} 666$

Total chlorophyll (CHLa $+\mathrm{CHLb})$

\section{Electrolyte Leakage:}

To determine the stability of the leaves' cell membrane, use was made of electrolyte leakage index (Marcom, 1998). In this method, 2-centimeter leaf segments were prepared. These segments were washed and placed in test tubes along with $10 \mathrm{ml}$ of distilled water. Next, the test tubes were shaken for a period of time between 17 and 18 hours (160rpm). In this stage, the electrical conductance of the test samples (E1) was measured in a conductivity meter device, Model JENWAY. Then, the test tubes were transferred to a $121^{\circ} \mathrm{C}$ autoclave for killing the leaf cells. This way, the electrical conductivity was carried out in this stage following the cooling of the contents of the test tubes (E2). In the end, the electrolyte leakage was calculated as shown in the following relation: $\mathrm{EL}=(\mathrm{E} 1 / \mathrm{E} 2) \times 100$.

\section{Morphological Traits:}

\section{Measured Traits:}

Plant Height: it was measured by a ruler in centimeter from the ring site to the tip of the main branch on the day ten after the last fertilization.

2.2.6.3. Number of Florets: the open and close florets were separately counted on the day ten after the last fertilization.

Number of Ancillary Branches: these were counted at the first and the last spraying attempts.

The time of the first florets' emergence in the first and second inflorescence turns: the date at which the first florets had appeared was recorded and after withering of the first stage's flowers, the date at which the second stage's flowers emerged was written down. 
The length of the flower cluster: all of the flower clusters in each pot were measured of their lengths using a ruler. Then, the mean values of the flower clusters were calculated for all of the pots and considered as the final value.

The wet weight of the aerial organs: the aerial organs (branches, leaves and flowers) were cut from the ring site and measured in laboratory by a scale with a precision rate of 0.001 .

Dry weight of the aerial organs: after cutting the aerial organs and weighing them, the plants were placed inside paper packets and incubated in a $70^{\circ} \mathrm{C}$ oven for $48 \mathrm{~h}$. Then, their dry weights were measured using a GF300 Scale with a precision rate of 0.001 .

Wet weight of the root: immediately after the destruction of the pots, the roots were completely washed under water and measured using a digital scale, model GF-300, with a precision rate of 0.001 . The roots were thoroughly extracted from inside the soil with minimum damage.

Dry weight of the root: the plants' roots and aerial organs were placed in a $70^{\circ} \mathrm{C}$ oven for $48 \mathrm{~h}$ for measuring the dry weight. Then, the dry weights were measured using a digital scale, model GF-300, with a precision rate of 0.001 . The ratio of the aerial organs to root $(\mathrm{S} / \mathrm{R})$ was obtained from dividing the dry weight of the aerial organs to the dry weight of the root.

Flower Persistence on Plant: this trait was measured visually by dividing the flower pots into four sections and considering a score percentage of 25 for each section. The flower persistence index was considered negative when the flowers had lost their beauty on the plant.

Statistical Analysis: to perform statistical analysis, use was made of JMP8 Software. The mean comparisons of the data were carried out by LSD test in a 5\% probability level and the diagrams were drawn in Excel.

\section{Results and Discussions:}

Based on the results obtained from variance analysis, the mutual effect of humic acid and iron oxide nanoparticles was significant increase in a $1 \%$ significance level on such traits as the length of the flower cluster, the flower persistence on plant, wet and dry weights of the root, wet and dry weights of the aerial organs, chlorophyll a, chlorophyll b, total chlorophyll, sugar amount, electrolyte leakage and total phenol. The simple effect of iron oxide nanoparticles was also significant increase in a $1 \%$ probability level in such traits as the wet weight of the aerial organs, wet weight of root, total chlorophyll, electrolyte leakage, soluble sugar and anthocyanin amount. The simple effect of humic acid was significant increase in a $1 \%$ probability level in such traits as electrolyte leakage, chlorophyll a, total chlorophyll, wet and dry weights of root and the dry weight of the aerial organs. But, none of the nutrition treatments exerted during the plants' growth stage was found having a significant effect on the plant height, number of the ancillary branches, number of nodes, number of open florets, number of close florets, number of total florets and the second flowering time (table 1).

Table 1: variance analysis of the measured traits (mean squares)

\begin{tabular}{|c|c|c|c|c|c|c|c|c|c|c|c|c|}
\hline $\begin{array}{l}\text { Variatio } \\
\text { ns } \\
\text { source }\end{array}$ & $\begin{array}{l}\text { Degr } \\
\text { ee of } \\
\text { freed } \\
\text { om }\end{array}$ & $\begin{array}{l}\text { Pla } \\
\text { nt } \\
\text { heig } \\
\text { ht }\end{array}$ & $\begin{array}{l}\text { Num } \\
\text { ber of } \\
\text { ancill } \\
\text { ary } \\
\text { branc } \\
\text { hes }\end{array}$ & $\begin{array}{l}\text { Num } \\
\text { ber } \\
\text { of } \\
\text { node } \\
\text { s }\end{array}$ & $\begin{array}{l}\text { Num } \\
\text { ber } \\
\text { of } \\
\text { total } \\
\text { floret } \\
\text { s }\end{array}$ & $\begin{array}{l}\text { Num } \\
\text { ber } \\
\text { of } \\
\text { open } \\
\text { floret } \\
\text { s }\end{array}$ & $\begin{array}{l}\text { Num } \\
\text { ber } \\
\text { of } \\
\text { close } \\
\text { floret } \\
\text { s }\end{array}$ & $\begin{array}{l}\text { First } \\
\text { flower } \\
\text { ing } \\
\text { stage }\end{array}$ & $\begin{array}{l}\text { Secon } \\
\mathrm{d} \\
\text { flower } \\
\text { ing } \\
\text { stage }\end{array}$ & $\begin{array}{l}\text { Wet } \\
\text { weig } \\
\text { ht of } \\
\text { the } \\
\text { aeria } \\
1 \\
\text { orga } \\
\text { ns }\end{array}$ & $\begin{array}{l}\text { Dry } \\
\text { wei } \\
\text { ght } \\
\text { of } \\
\text { the } \\
\text { aeri } \\
\text { al } \\
\text { orga } \\
\text { ns }\end{array}$ & $\begin{array}{l}\text { Anthocy } \\
\text { anin }\end{array}$ \\
\hline $\begin{array}{l}\text { Iron } \\
\text { oxide } \\
\text { nanopart } \\
\text { icles }\end{array}$ & 3 & $\begin{array}{l}5.6 \\
2^{\text {ns }}\end{array}$ & ${ }_{\mathrm{ns}}^{11.13}$ & $\frac{1.22}{\mathrm{~ns}}$ & ${ }_{\mathrm{ns}}^{1434}$ & $623^{\mathrm{ns}}$ & ${ }_{\mathrm{ns}}^{1456}$ & $1.81^{\mathrm{ns}}$ & $0.69^{\mathrm{ns}}$ & $\begin{array}{l}19.3 \\
8^{*}\end{array}$ & $\begin{array}{l}8.2 \\
\mathrm{~ns}\end{array}$ & $2656^{* *}$ \\
\hline $\begin{array}{l}\text { Humic } \\
\text { acid }\end{array}$ & 3 & $\begin{array}{l}2.1 \\
2^{\text {ns }}\end{array}$ & $\begin{array}{l}6.69 \\
\text { ns }\end{array}$ & 2.89 & 1241 & $\operatorname{ns}_{\mathrm{ns}}^{1576}$ & $728^{\mathrm{ns}}$ & $3.35^{*}$ & $0.95^{\mathrm{ns}}$ & $\underset{\mathrm{ns}}{299}$ & $\begin{array}{l}68.7 \\
* *\end{array}$ & $1309^{*}$ \\
\hline $\begin{array}{l}\text { Iron } \\
\text { oxide } \\
\text { nanopart } \\
\text { icles } ~ \\
\text { humic } \\
\text { acid } \\
\end{array}$ & 9 & $\begin{array}{l}9.4 \\
6^{\text {ns }}\end{array}$ & 1.38 & $\begin{array}{l}0.46 \\
\text { ns }\end{array}$ & 1055 & $856^{\mathrm{ns}}$ & $659^{\mathrm{ns}}$ & $1.29^{\mathrm{ns}}$ & $0.49^{\mathrm{ns}}$ & $\begin{array}{l}1604 \\
* *\end{array}$ & $\begin{array}{l}58.9 \\
* *\end{array}$ & $3407^{* *}$ \\
\hline Error & 32 & 6 & 6.92 & 1.13 & 1080 & 921 & 1025 & 0.9 & 0.36 & 486 & 13 & 316 \\
\hline
\end{tabular}


Table (1) continued:

\begin{tabular}{|c|c|c|c|c|c|c|c|c|c|c|c|}
\hline $\begin{array}{l}\text { Variation } \\
\text { s source }\end{array}$ & $\begin{array}{l}\text { Degre } \\
\mathrm{e} \quad \text { of } \\
\text { freed } \\
\text { om }\end{array}$ & $\begin{array}{l}\text { Chlorop } \\
\text { hyll a }\end{array}$ & $\begin{array}{l}\text { Chlorop } \\
\text { hyll b }\end{array}$ & $\begin{array}{l}\text { Total } \\
\text { chlorop } \\
\text { hyll }\end{array}$ & $\begin{array}{l}\text { Wet } \\
\text { root } \\
\text { weig } \\
\text { ht }\end{array}$ & $\begin{array}{l}\text { Dry } \\
\text { root } \\
\text { weig } \\
\text { ht }\end{array}$ & $\begin{array}{l}\text { Flow } \\
\text { er } \\
\text { cluste } \\
\text { r's } \\
\text { lengt } \\
\text { h }\end{array}$ & $\begin{array}{l}\text { Tota } \\
1 \\
\text { phen } \\
\text { ol }\end{array}$ & $\begin{array}{l}\text { Solu } \\
\text { ble } \\
\text { sugar }\end{array}$ & $\begin{array}{l}\text { Electrol } \\
\text { yte } \\
\text { leakage }\end{array}$ & $\begin{array}{l}\text { Flow } \\
\text { er life } \\
\text { on } \\
\text { plant }\end{array}$ \\
\hline $\begin{array}{l}\text { Iron } \\
\text { oxide } \\
\text { nanoparti } \\
\text { cles }\end{array}$ & 3 & $5.1^{*}$ & $13.6^{\mathrm{ns}}$ & $30.9^{* *}$ & $\begin{array}{l}30.5 \\
* *\end{array}$ & $\begin{array}{l}0.02 \\
\text { ns }\end{array}$ & $1.26^{*}$ & $\begin{array}{l}0.18 \\
\text { ns }\end{array}$ & $\begin{array}{l}0.05 \\
* *\end{array}$ & $22.3^{\mathrm{ns}}$ & $\underset{\mathrm{ns}}{338.2}$ \\
\hline $\begin{array}{l}\text { Humic } \\
\text { acid }\end{array}$ & 3 & $63.4^{* *}$ & $11.1^{\mathrm{ns}}$ & $80.5^{* *}$ & $\begin{array}{l}13.6 \\
* *\end{array}$ & $\begin{array}{l}0.28 \\
* *\end{array}$ & $\begin{array}{l}0.66 \\
\text { ns }\end{array}$ & $\begin{array}{l}0.02 \\
\mathrm{~ns}\end{array}$ & $\begin{array}{l}0.01 \\
\mathrm{~ns}\end{array}$ & $56.1^{\text {ns }}$ & $\begin{array}{l}421.4 \\
\text { ns }\end{array}$ \\
\hline $\begin{array}{l}\text { Iron } \\
\text { oxide } \\
\text { nanoparti } \\
\text { cles } \quad \times \\
\text { humic } \\
\text { acid }\end{array}$ & 9 & $19.4^{* *}$ & $28^{* *}$ & $57.7^{* *}$ & $\begin{array}{l}13.9 \\
* *\end{array}$ & $\begin{array}{l}0.27 \\
* *\end{array}$ & $\begin{array}{l}1.05^{*} \\
*\end{array}$ & $\begin{array}{l}1.36 \\
* *\end{array}$ & $\begin{array}{l}0.02 \\
* *\end{array}$ & $29.8^{\mathrm{ns}}$ & $\begin{array}{l}856.6 \\
* *\end{array}$ \\
\hline Error & 32 & 1.6 & 7.7 & 6.9 & 0.3 & 0.01 & 0.3 & 0.08 & $\begin{array}{l}0.00 \\
6 \\
\end{array}$ & 1.9 & 215.3 \\
\hline
\end{tabular}

Table 2: mean comparisons of the simple effect of various levels of iron oxide nanoparticles on the measured traits

\begin{tabular}{|c|c|c|c|c|c|c|c|c|}
\hline Treatment & $\begin{array}{l}\text { Electrolyte } \\
\text { leakage } \\
(\%)\end{array}$ & $\begin{array}{l}\text { Chlorophyll } \\
\text { a (mg/g) }\end{array}$ & $\begin{array}{l}\text { Total } \\
\text { chlorophyll } \\
(\mathrm{mg} / \mathrm{g})\end{array}$ & $\begin{array}{l}\text { Amount } \\
\text { of } \\
\text { soluble } \\
\text { sugar } \\
(\mathrm{mg} / \mathrm{g})\end{array}$ & $\begin{array}{l}\text { Wet } \\
\text { root } \\
\text { weight } \\
(\mathrm{mg} / \mathrm{g})\end{array}$ & $\begin{array}{l}\text { Wet } \\
\text { weight } \\
\text { of the } \\
\text { aerial } \\
\text { parts } \\
(\mathrm{mg} / \mathrm{g})\end{array}$ & $\begin{array}{l}\text { Flower } \\
\text { cluster } \\
\text { length } \\
(\mathrm{cm})\end{array}$ & $\begin{array}{l}\text { Anthocyanin } \\
\text { amount } \\
\text { (mg/g) }\end{array}$ \\
\hline $0 \mathrm{mg} / 1$ & $26.85^{\mathrm{a}}$ & $11.29^{\mathrm{a}}$ & $22.89^{\mathrm{ab}}$ & $0.54^{\mathrm{b}}$ & $7.25^{b}$ & $0.22^{\mathrm{b}}$ & $4.23^{\mathrm{b}}$ & $1160^{\mathrm{c}}$ \\
\hline $150 \mathrm{mg} / \mathrm{l}$ & $26.19^{a}$ & $10.09^{b}$ & $21.33^{b}$ & $0.68^{\mathrm{a}}$ & $10.54^{\mathrm{a}}$ & $0.22^{b}$ & $4.11^{\mathrm{b}}$ & $1366^{\mathrm{b}}$ \\
\hline $300 \mathrm{mg} / \mathrm{l}$ & $26.74^{\mathrm{a}}$ & $11.48^{\mathrm{a}}$ & $24.44^{\mathrm{a}}$ & $0.69^{\mathrm{a}}$ & $10.39^{\mathrm{a}}$ & $0.25^{\mathrm{ab}}$ & $4.48^{\mathrm{ab}}$ & $1520^{\mathrm{a}}$ \\
\hline $450 \mathrm{mg} / 1$ & $23.93^{b}$ & $10.50^{\mathrm{ab}}$ & $20.92^{b}$ & $0.61^{\mathrm{b}}$ & $10.37^{\mathrm{a}}$ & $0.24^{\mathrm{a}}$ & $4.85^{\mathrm{a}}$ & $1311^{b}$ \\
\hline
\end{tabular}

Table 3: mean comparisons of the simple effect of various levels of humic acid on the measured traits

\begin{tabular}{|l|l|l|l|l|l|l|l|l|}
\hline Treatment & $\begin{array}{l}\text { Electrolyte } \\
\text { leakage } \\
(\%)\end{array}$ & $\begin{array}{l}\text { Chlorophyll } \\
\mathrm{a}(\mathrm{mg} / \mathrm{g})\end{array}$ & $\begin{array}{l}\text { Total } \\
\text { chlorophyll } \\
(\mathrm{mg} / \mathrm{g})\end{array}$ & $\begin{array}{l}\text { First } \\
\text { flowering } \\
\text { stage } \\
(\text { days })\end{array}$ & $\begin{array}{l}\text { Wet } \\
\text { root } \\
\text { weight } \\
(\mathrm{mg} / \mathrm{g})\end{array}$ & $\begin{array}{l}\text { Dry } \\
\text { root } \\
\text { weight } \\
(\mathrm{mg} / \mathrm{g})\end{array}$ & $\begin{array}{l}\text { Dry } \\
\text { weight } \\
\text { of } \\
\text { aerial } \\
\text { arts } \\
(\mathrm{mg} / \mathrm{g})\end{array}$ & $\begin{array}{l}\text { Anthocyanin } \\
\text { amount } \\
(\mathrm{mg} / \mathrm{g})\end{array}$ \\
\hline $0 \mathrm{mg} / 1$ & $27.88^{\mathrm{a}}$ & $7.41^{\mathrm{b}}$ & $18.94^{\mathrm{c}}$ & $0.91^{\mathrm{b}}$ & $10.10^{\mathrm{a}}$ & $1.77^{\mathrm{a}}$ & $0.02^{\mathrm{b}}$ & $1339^{\mathrm{ab}}$ \\
\hline $50 \mathrm{mg} / 1$ & $25.35^{\mathrm{b}}$ & $12.18^{\mathrm{a}}$ & $24.25^{\mathrm{a}}$ & $0.75^{\mathrm{b}}$ & $8.04^{\mathrm{b}}$ & $1.43^{\mathrm{b}}$ & $0.03^{\mathrm{a}}$ & $1210^{\mathrm{b}}$ \\
\hline $100 \mathrm{mg} / 1$ & $22.37^{\mathrm{c}}$ & $12.12^{\mathrm{a}}$ & $24.52^{\mathrm{a}}$ & $0.66^{\mathrm{ab}}$ & $10.12^{\mathrm{a}}$ & $1.49^{\mathrm{b}}$ & $0.03^{\mathrm{a}}$ & $1210^{\mathrm{b}}$ \\
\hline $200 \mathrm{mg} / 1$ & $28.11^{\mathrm{a}}$ & $11.66^{\mathrm{a}}$ & $21.87^{\mathrm{b}}$ & $0.29^{\mathrm{a}}$ & $10.29^{\mathrm{a}}$ & $1.51^{\mathrm{b}}$ & $0.02^{\mathrm{b}}$ & $1456^{\mathrm{a}}$ \\
\hline $\begin{array}{l}\text { In every column, the treatments having at least one letter in common are not significant based on LSD test in a } \\
5 \% \text { probability level. }\end{array}$ \\
\hline
\end{tabular}


Comparing the Morphological Traits of Snapdragon (Montego Rose Bicolor Variety) Subject to Such Nutrition Treatments as Iron Oxide Nanoparticles, Humic Acid and Their Mutual Effects

\section{1) Plant Height:}

In this experiment, iron oxide nanoparticles and humic acid treatments were not found having significant effects on such traits as plant height, number of ancillary branches, number of nodes, total number of florets, number of open florets, number of close florets and acceleration of second stage inflorescence (table 1). It was observed in a study on eggplant and capsicum plantlets that humic acid spraying does not significantly influence the plant height (Padem et al, 1999). Application of humic acid was not found also significantly influencing the stalk height, as well (Afshinmanesh et al, 2012).

\section{2) Wet Weight of Aerial Parts:}

The mutual effect of iron oxide nanoparticles and humic acid: the obtained results indicated that iron oxide nanoparticles and humic acid treatments have mutual effects on the wet weight of the aerial parts. The highest wet weights were $450 \mathrm{mg} / 1$ (level 4) and 100mg/l (level 3) for iron oxide nanoparticles and humic acid treatments, respectively; the lowest wet weights were $150 \mathrm{mg} / 1$ (level 2) and 50mg/l (level 2) for iron oxide nanoparticles and humic acid treatments, respectively (figure 1).

The results are reflective of the idea that the application of humic acid in low amounts does not exert significant effect on the weight of radish stalk. Spraying humic acid for an amount of $300 \mathrm{mg} / 1$ was found bringing about a significant increase in the wet weight of the stem in tomatoes.

In addition, application of higher concentrations caused growth inhibition and deformation of the leaves. Application of $300 \mathrm{mg} / 1$ humic acid caused increase in the wet weight of the aerial parts in wheat (Sabzevari et al, 2009). According to the fact that iron is one of the important elements in reductive-oxidative reactions of the plants and also plays a considerable role in plants' photosynthesis, iron oxide nanoparticle fertilizers' application causes growth in the aerial parts. It can also be expected that the use of these ingredients, meanwhile providing the plants with the nutrients needed, causes an increase in the growing body and biomass production, as well (Gardner et al, 2011).

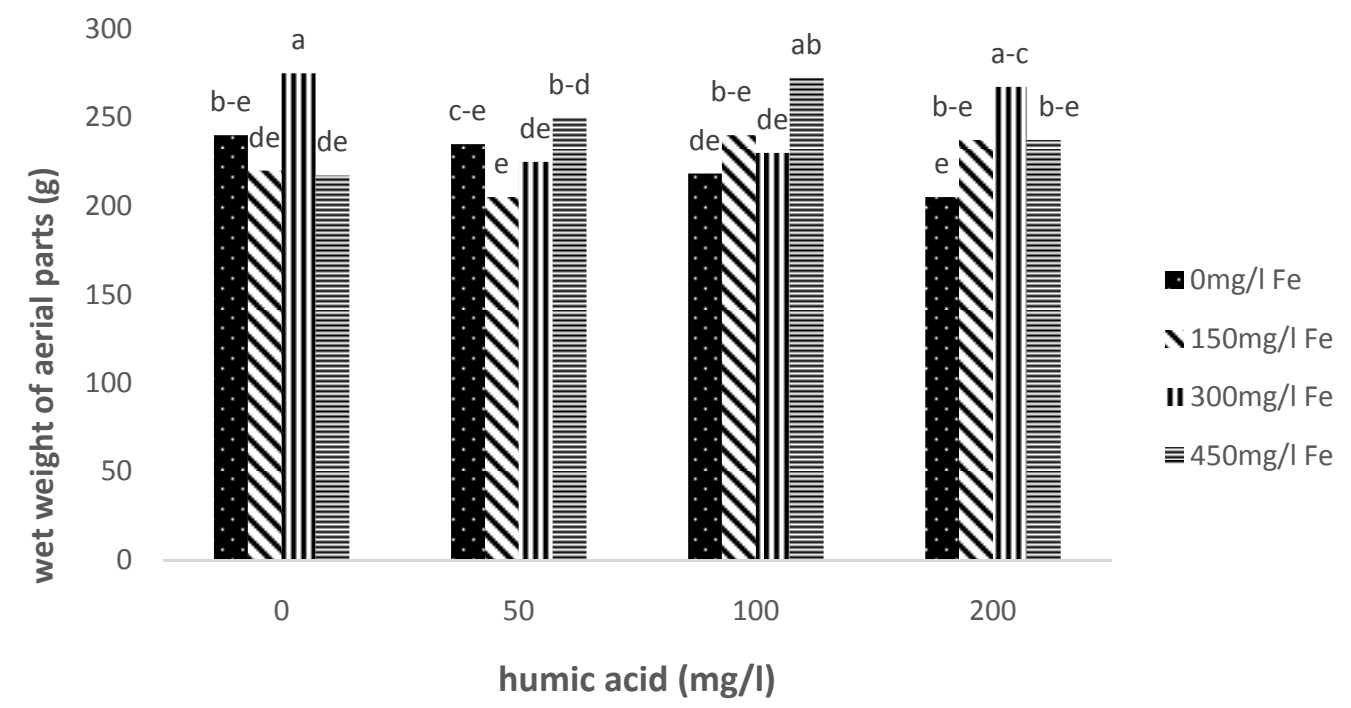

Figure (1): the mutual effect of iron oxide nanoparticles and humic acid application on the wet weight of the aerial parts in snapdragon

3) Dry Weight of the Aerial Parts:

The mutual effect of iron oxide nanoparticles and humic acid: the results showed it that the mutual effect of iron oxide nanoparticles and humic acid causes significant difference in terms of the dry weight of the aerial parts. The highest dry weights of the aerial parts were found in $450 \mathrm{mg} / 1$ iron oxide nanoparticles treatment (level 4) and 100mg/l humic acid treatment (level 3) and the lowest dry weights of the aerial parts were scored for $450 \mathrm{mg} / 1$ iron oxide nanoparticles treatment (level 4) and 0mg/l humic acid treatments (level 1) (figure 2-4). It has been figured out that the application of humic fertilizers in the periphery of black-eyed peas' roots causes an increase in the dry weight of the aerial parts.

It was made clear in a study that the use of humic acid causes an increase in the dry weight of the leaf and stalk of the capsicum plants (Gulser et al, 2010). The experimental results indicated that the use of various amounts of less frequently consumed elements causes an increase in the dry weight of the tarragon plants. It was found out after spraying tomatoes with $300 \mathrm{mg} / \mathrm{l}$ of humic acid that the wet and dry stem weights have been increased. 


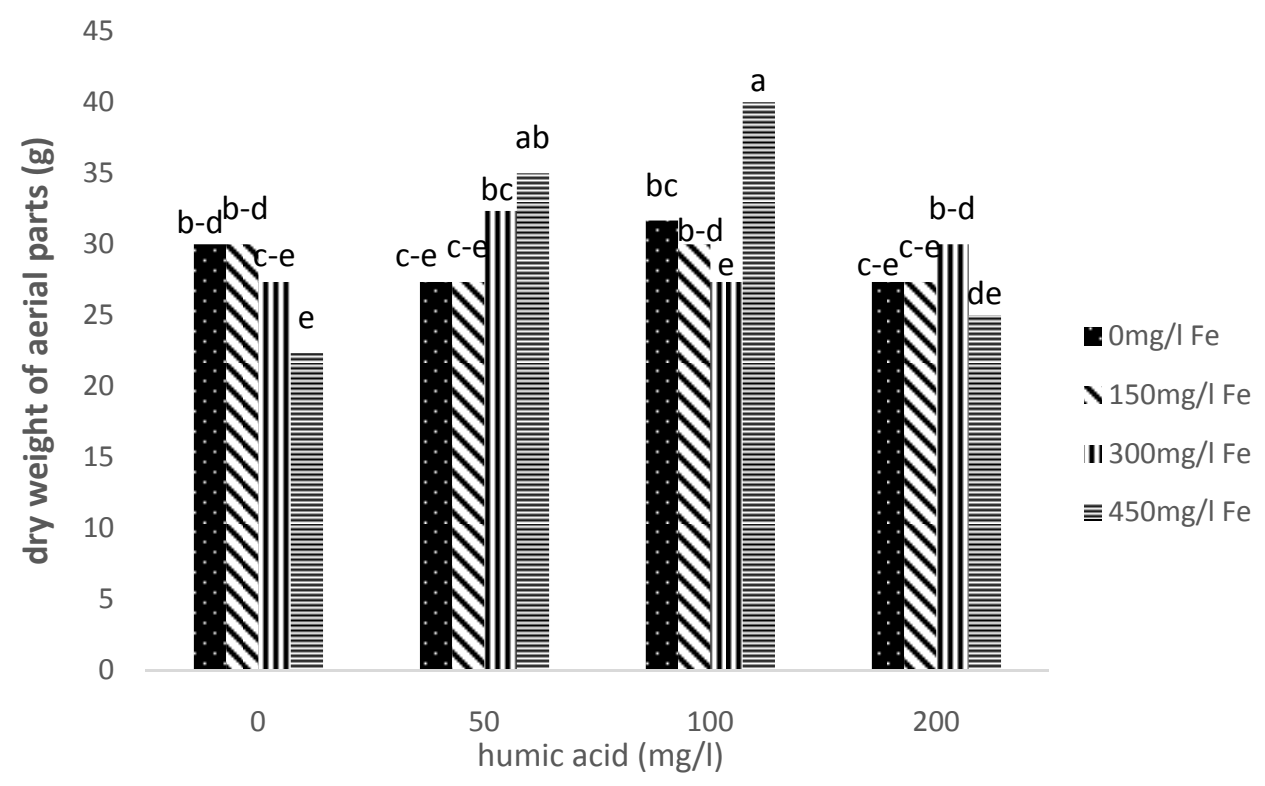

Figure (2): the mutual effects of iron oxide nanoparticles and humic acid treatments on the dry weight of the aerial parts

\section{4-1) Wet Root Weight:}

The mutual effect of iron oxide nanoparticles and humic acid treatments: the results showed it to us that the mutual effects of iron oxide nanoparticles and humic acid treatments cause significant differences in terms of the wet weight of root. The highest wet root weights were documented for $150 \mathrm{mg} / \mathrm{l}$ iron oxide nanoparticles treatment (level 2) and 100mg/l humic acid treatment (level 3) and the lowest wet root weights were evidenced in $150 \mathrm{mg} / \mathrm{l}$ iron oxide nanoparticles treatment (level 2) and 50mg/l humic acid treatment (level 2) (figure 3). Application of humic acid influences the growth and performance of the root more than those of the aerial parts. The effect stems from the increase in the uptake of the nutritional elements by the roots. In other words, since the nutrients are in direct contact with root surface, the increase in the availability of the nutrients following the application of humic acid can more effectively influence root performance.

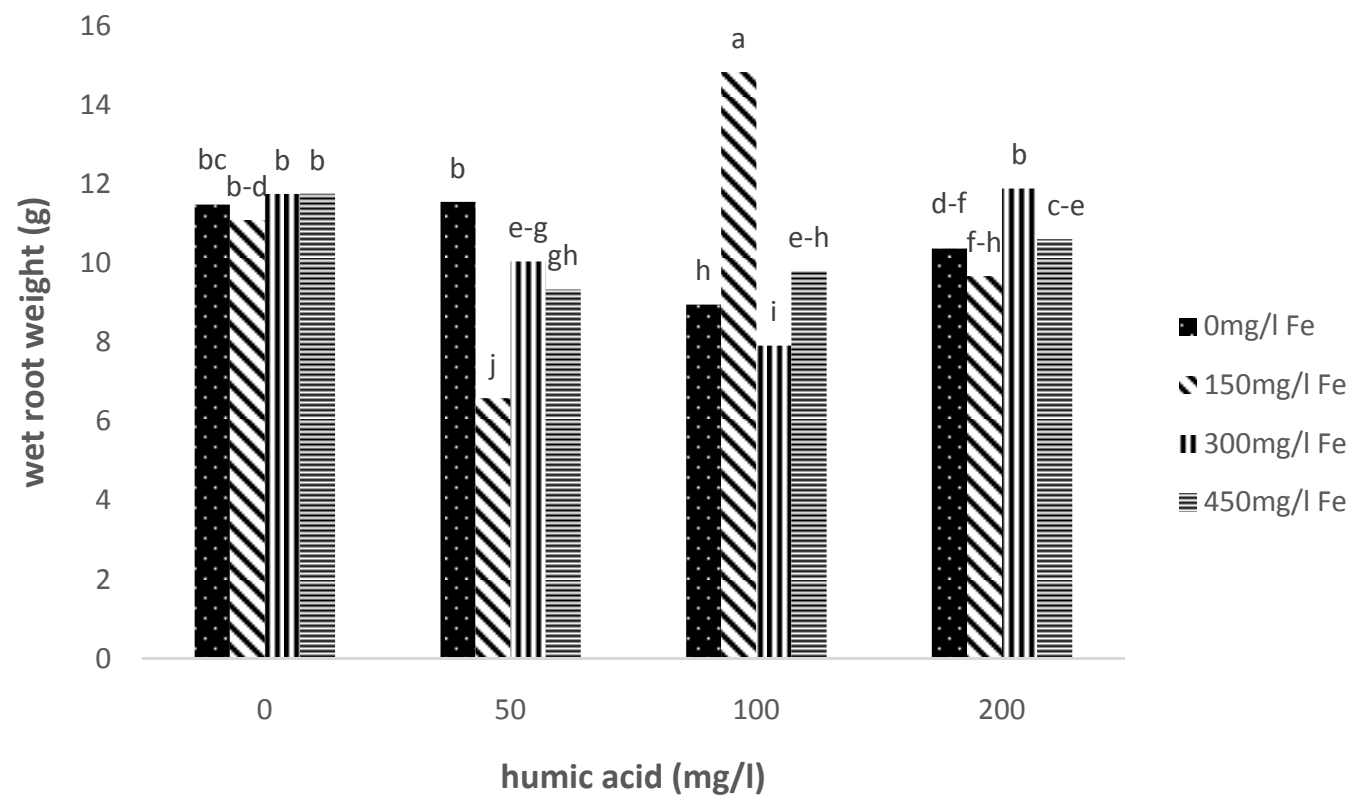

Figure (3): mutual effects of applying iron oxide nanoparticles and humic acid on wet weights of snapdragon's roots 


\section{5- Dry Root Weight:}

The mutual effects of iron oxide nanoparticles and humic acid: the results demonstrated that the mutual effect of iron oxide nanoparticles and humic acid treatments cause significant differences in terms of the dry root weight. The highest dry root weights were documented for $150 \mathrm{mg} / 1$ iron oxide nanoparticles treatment (level 2) and $100 \mathrm{mg} / \mathrm{l}$ humic acid treatment (level 3) (figure 4).

Application of humic acid for concentrations between $250 \mathrm{mg} / \mathrm{kg}$ and $1000 \mathrm{mg} / \mathrm{kg}$ on soil causes an increase in the dry weights of the stalk and root in such plants as capsicum, tomato, strawberry and marigold (Arancon et al, 2003). The increase in the dry weights of root and aerial parts following the application of humic acid should be realized as having been caused by the quasi-hormone effects of this organic material that incites root growth. Additionally, application of humic acid on soil brings about an increase in the nutrients of the soil that can per se improve the plant's growth. It has been shown by the researchers that $30 \mathrm{~kg} / \mathrm{ha}$ of humic acid significantly increases the performance of the root's dry matter. Of course, the root to stem ratio was found more increased (Atiyeh et al, 2002).

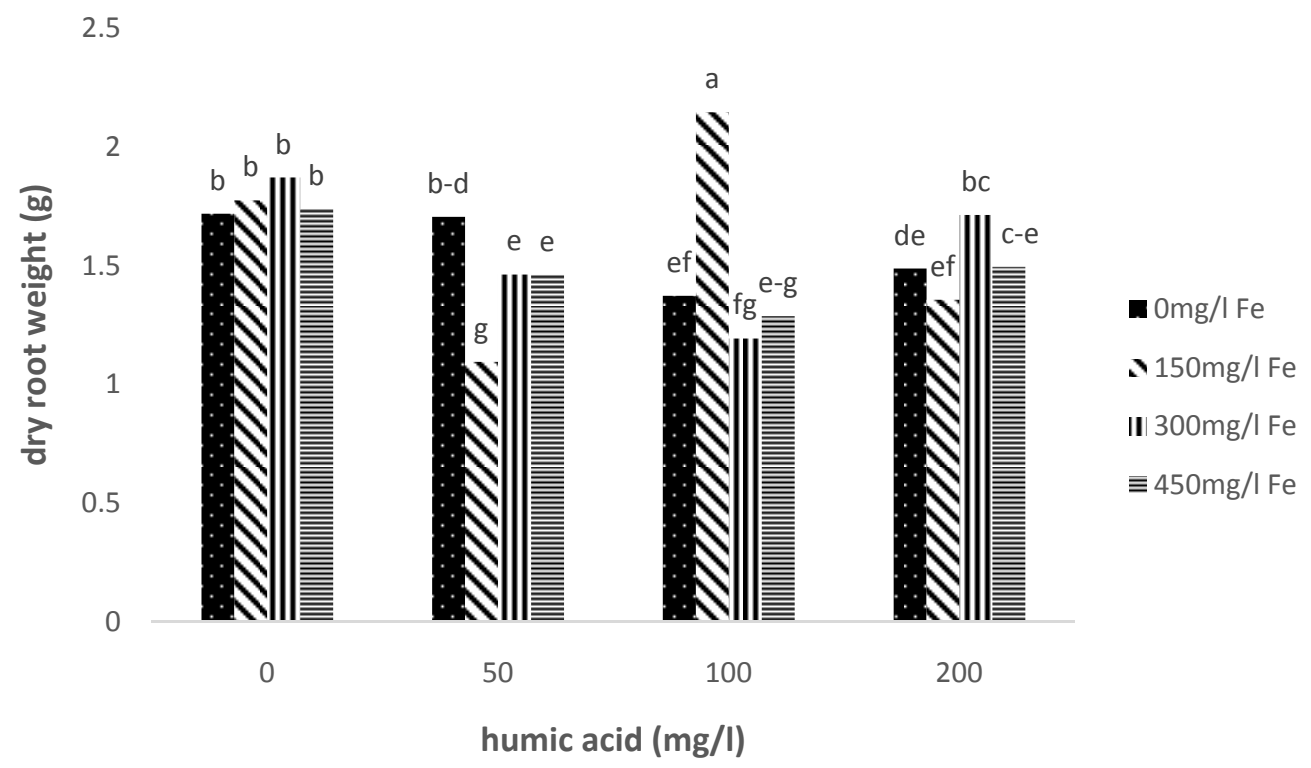

Figure (4): the mutual effects of iron oxide nanoparticles and humic acid application on dry weight of snapdragon's root

\section{6- Flower Cluster Length:}

The mutual effect of iron oxide nanoparticles and humic acid: the results showed that the mutual effects of iron oxide nanoparticles and humic acid cause significant differences in terms of the length of flower cluster. The highest lengths of flower cluster were found belonging to $450 \mathrm{mg} / 1$ iron oxide nanoparticles treatment (level 4) and 50mg/l humic acid treatment (level 2) and the lowest lengths of flower cluster belonged to $450 \mathrm{mg} / 1$ iron oxide nanoparticles treatment (level 4) and $0 \mathrm{mg} / \mathrm{l}$ humic acid treatment (level 1) (figure 5). 


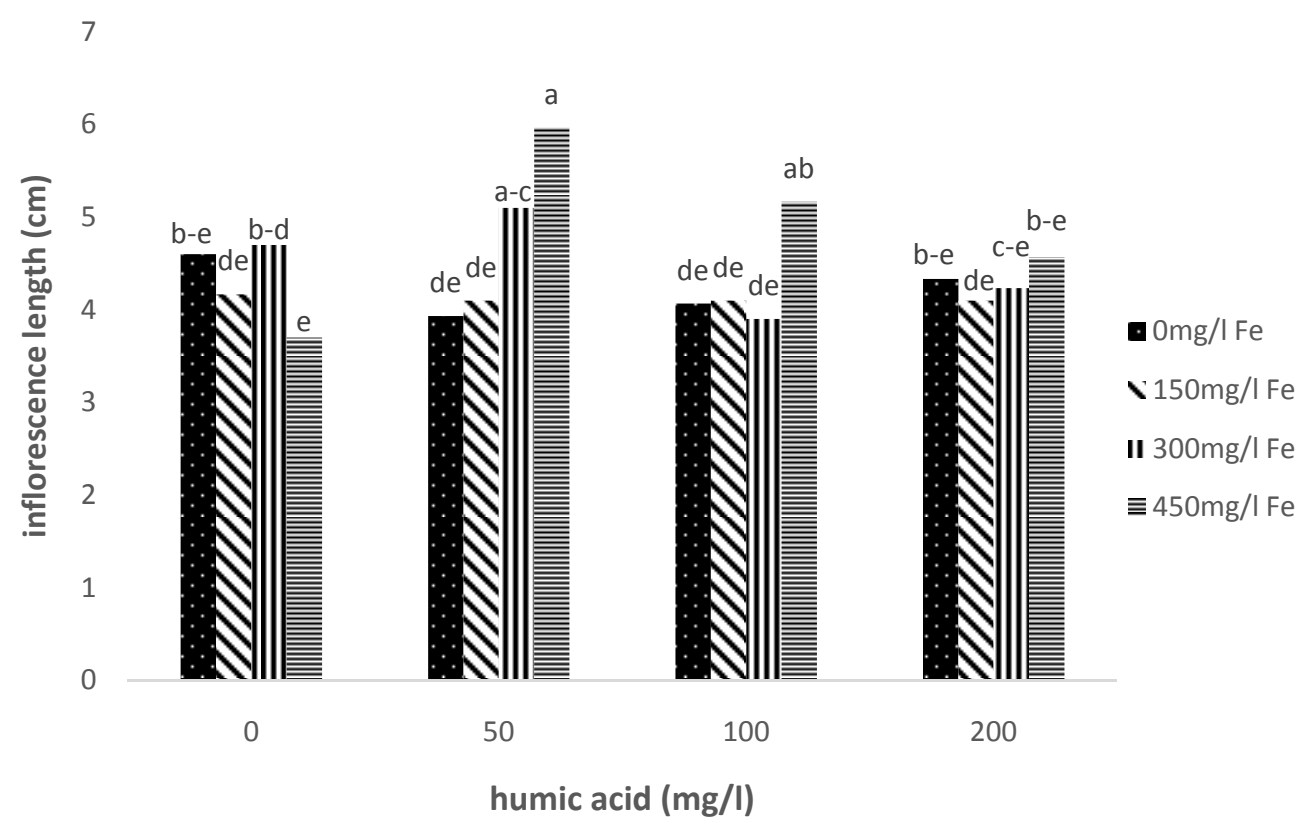

Figure (5): the mutual effects of iron oxide nanoparticles and humic acid application on inflorescence length

\section{7- Flower Persistence on Plant:}

The mutual effect of iron oxide nanoparticle and humic acid treatments: the results indicated that the mutual effects of iron oxide nanoparticles and humic acid treatments cause significant differences in terms of the flower life length. The highest lengths of the flowers' life on plant were found for $150 \mathrm{mg} / \mathrm{l}$ iron oxide nanoparticles' treatment (level 2) and $0 \mathrm{mg} / \mathrm{l}$ humic acid treatment (level 1) and the lowest flower persistence on the plant was found belonging to the evidence treatment (figure 6).

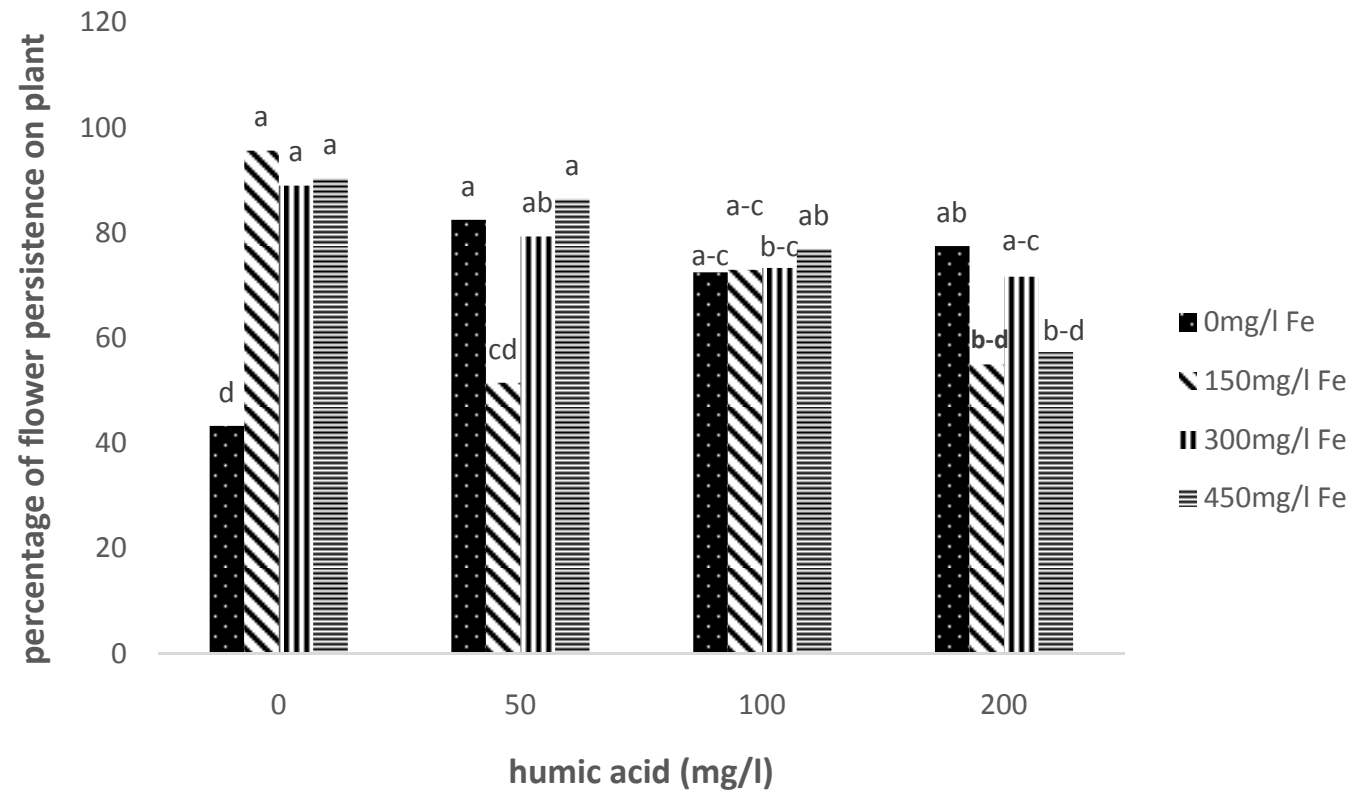

Figure (6): the mutual effects of applying iron oxide nanoparticles and humic acid treatments on the persistence of flower on plants 


\section{Comparison of Biochemical Traits:}

\subsection{Chlorophyll a:}

The mutual effects of iron oxide nanoparticles and humic acid treatments: the results showed that the mutual effects of iron oxide nanoparticles and humic acid cause significant differences in terms of chlorophyll a. The highest chlorophyll a contents were found belonging to $150 \mathrm{mg} / \mathrm{l}$ iron oxide nanoparticles' treatment (level 2) and $100 \mathrm{mg} / 1$ humic acid treatment (level 3 ) and the lowest chlorophyll a contents belonged to $150 \mathrm{mg} / \mathrm{l}$ iron oxide nanoparticles' treatment (level 2) and 0mg/l humic acid treatment (level 1) (figure 7). It is reported that the humic materials cause an increase in the uptake of nutrients, including nitrogen, thereby bringing about an increase in chlorophyll and photosynthesis that can eventually improve plant growth (Dowlatiyan et al, 2013). Based on a research that was conducted on borage, the increase in humic acid concentration from zero to $3 \mathrm{ml} / \mathrm{L}$ causes an addition to chlorophyll a and $\mathrm{b}$ and the increase in humic acid by $6 \mathrm{ml} / \mathrm{L}$ was found having a reducing effect on chlorophyll content. It has been stated in a research that humic acid application causes an increase in chlorophyll content, especially chlorophyll a (Nasirpour et al, 2014).

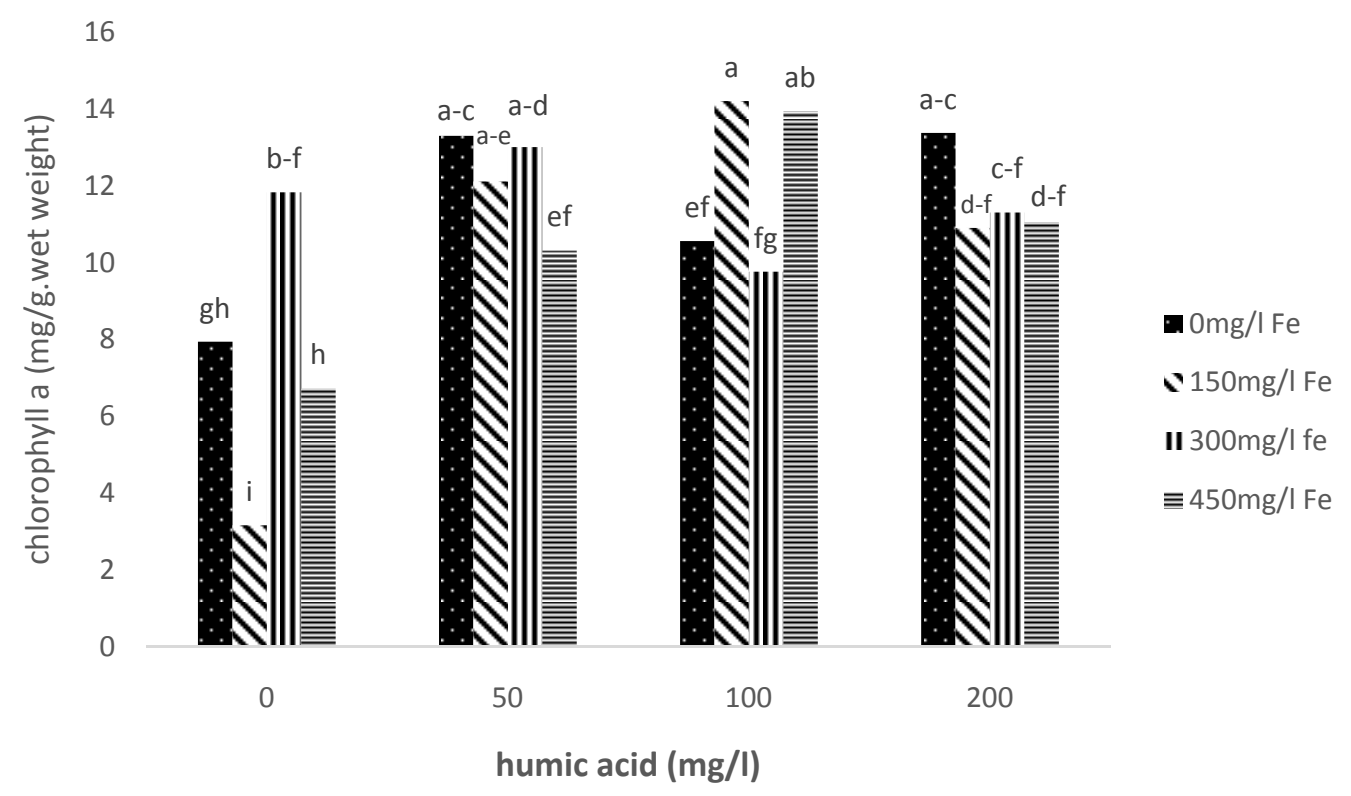

Figure (7): mutual effects of iron oxide nanoparticles and humic acid treatments on chlorophyll a contents of snapdragon's leaves

\subsection{Chlorophyll b:}

The mutual effects of iron oxide nanoparticles and humic acid treatments: the results indicated that the mutual effects of iron oxide nanoparticles and humic acid treatments cause significant differences in terms of chlorophyll b. the highest chlorophyll b index was found belonging to $300 \mathrm{mg} / 1$ iron oxide nanoparticles' treatment (level 3) and 50mg/l humic acid treatment (level 2) and the lowest chlorophyll b contents were scored for $450 \mathrm{mg} / 1$ iron oxide nanoparticles' treatment (level 4) and 0mg/l humic acid treatment (level 1) (figure 8). Humic acid was found bringing about a significant increase in chlorophyll b contents of capsicum leaves (Caracout et al, 2008). The effect of humic acid on the performance and quality of capsicums was investigated in five concentrations applied as either foliar sprays or topsoil fertilization. The sugar content of the fruits following the application of humic acid was found significantly increased in both of the methods. It was also figured out that humic acid significantly influences the leaves' chlorophyll content and that it has its greatest effects on the chlorophyll b content. Humic acid's soil application or foliar spray for an amount of $20 \mathrm{ml}$ per every liter of water was found maximally increasing the leaves' chlorophyll. 


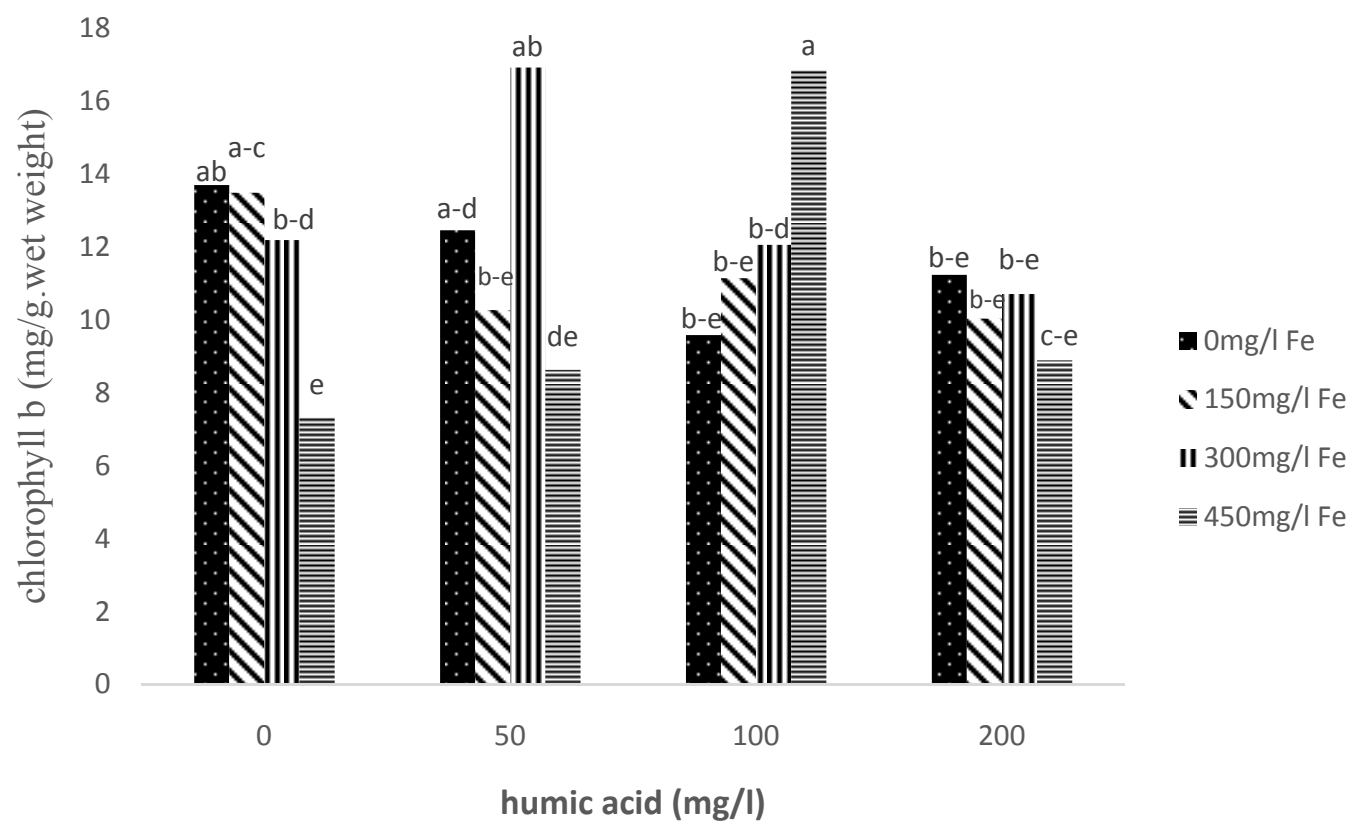

Figure (8): mutual effects of iron oxide nanoparticles and humic acid applications on chlorophyll b of snapdragon's leaves

\subsection{Total Chlorophyll:}

The mutual effects of iron oxide nanoparticles and humic acid: the results demonstrated that the mutual effects of iron oxide nanoparticles and humic acid cause significant differences in terms of total chlorophyll content. The highest total chlorophyll contents were found for $450 \mathrm{mg} / 1$ iron oxide nanoparticles' treatment (level 4) and $100 \mathrm{mg} / 1$ humic acid (level 3) and the lowest total chlorophyll contents belonged to $450 \mathrm{mg} / 1$ iron oxide nanoparticles' treatment (level 4) and $0 \mathrm{mg} / \mathrm{l}$ humic acid treatment (level 1) (figure 9). Iron use was found increasing chlorophyll content of the peanuts during flowering stage (Singh et al, 1990). Iron sprays have been reported to increase photosynthesis intensity, net uptake and relative growth in rice subject to salt stress.

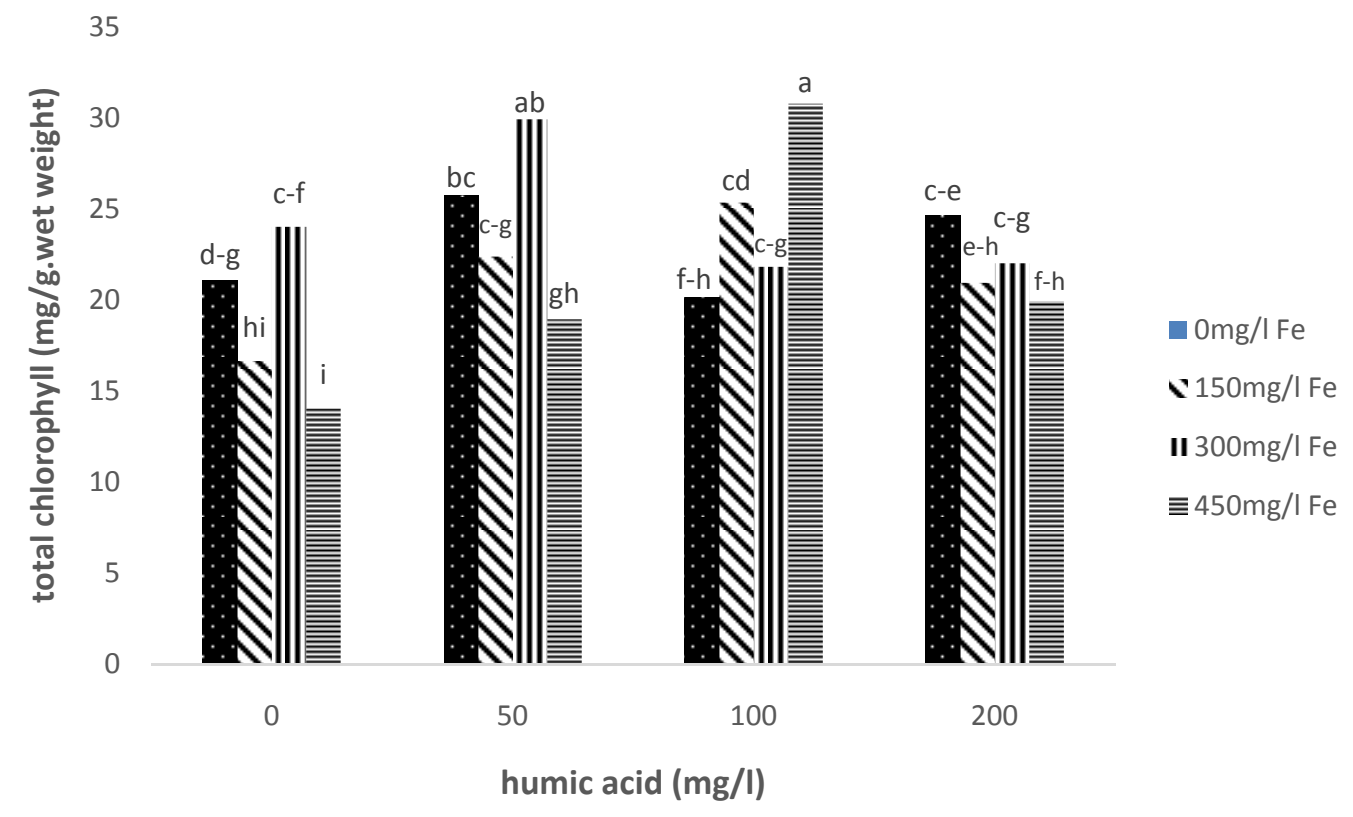

Figure (9): mutual effects of iron oxide nanoparticles and humic acid application on total chlorophyll content of snapdragon's leaves 


\subsection{Total Phenol:}

Mutual effects of iron oxide nanoparticles and humic acid treatments: the results showed that the mutual effects of iron oxide nanoparticles and humic acid treatments cause significant differences in terms of total phenol in such a way that the highest phenol content was found obtained in $150 \mathrm{mg} / \mathrm{l}$ iron oxide nanoparticles' treatment (level 2) and $0 \mathrm{mg} / \mathrm{l}$ humic acid treatment (level 1); the lowest phenol content was found for $0 \mathrm{mg} / \mathrm{l}$ iron oxide nanoparticles' treatment (level 1) and 100mg/l humic acid treatment (level 3) (figure 10). Humic acid significantly influences phenol, antioxidants and soluble sugars' contents; the effect was found having reached its maximum amount for $400 \mathrm{mg} / \mathrm{l}$ humic acid treatment of purslane. The chemical traits were found in an ascending trend with the increase in humic acid level (Singh et al, 1990).

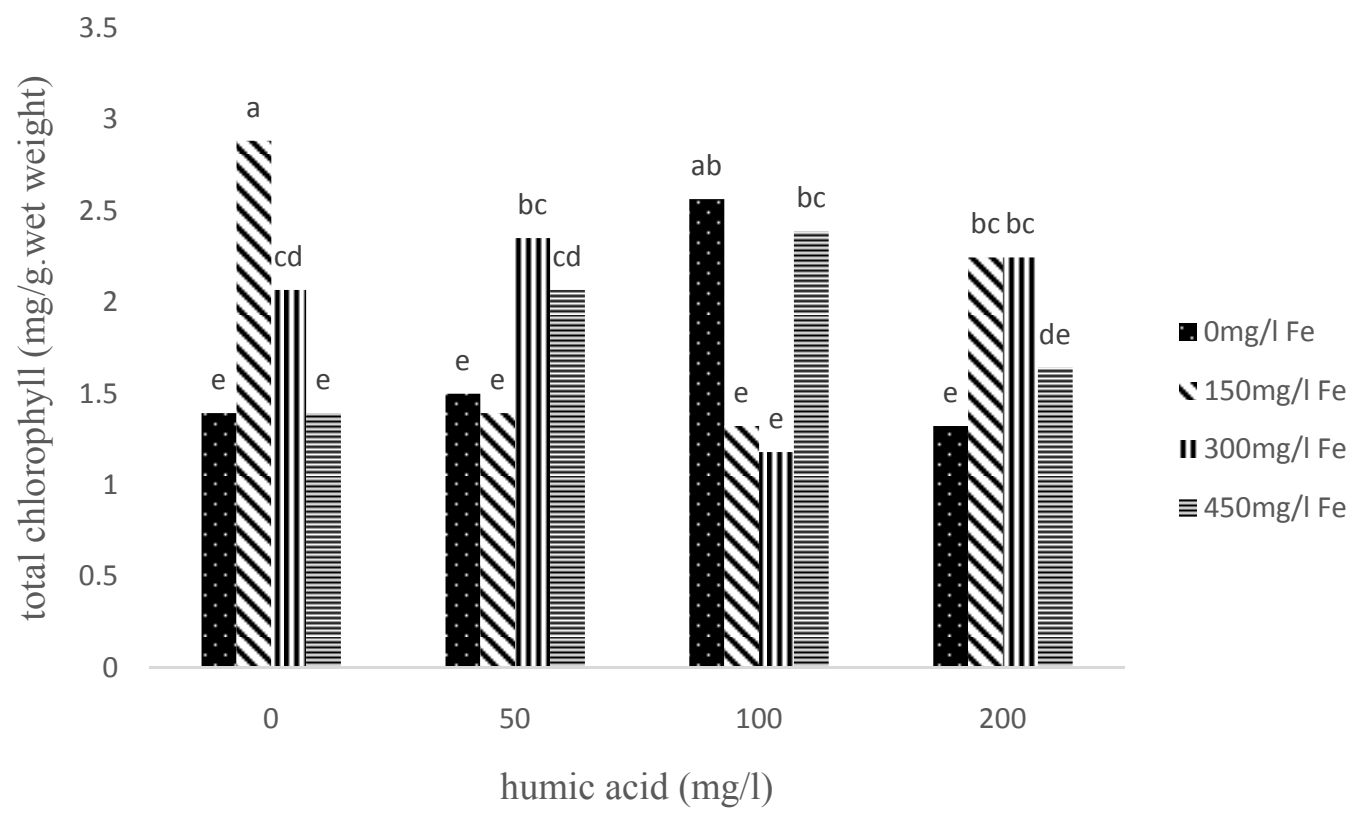

Figure (10): the mutual effects of iron oxide nanoparticles and humic acid applications on total phenol of snapdragon

\subsection{Soluble Sugar:}

Mutual effects of iron oxide nanoparticles and humic acid treatments: the results showed that the mutual effects of iron oxide nanoparticles and humic acid treatments cause significant differences in terms of soluble sugar in such a way that the highest soluble sugar amount was obtained for $300 \mathrm{mg} / \mathrm{l}$ iron oxide nanoparticles' treatment (level 3) in contrast to the three preliminary levels of humic acid application $(0 \mathrm{mg} / 1,50 \mathrm{mg} / 1$ and $100 \mathrm{mg} / \mathrm{l})$ (figure 11). It has been found out in an application of humic acid on tomatoes that the total sugar, vitamin, ascorbic acid, dry weight of the plant and chlorophyll a and $\mathrm{b}$ pigments are increased. The chlorophyll and sugar contents were measured at the ripening time of apricot fruits. The results indicated that all treatments' results significantly differ from those of the evidence treatment (no foliar sprays). It was also shown that substitution of iron fertilizers prepared based on nanotechnology can be more effective for suitable or lower concentrations in comparison to the common iron fertilizers. 


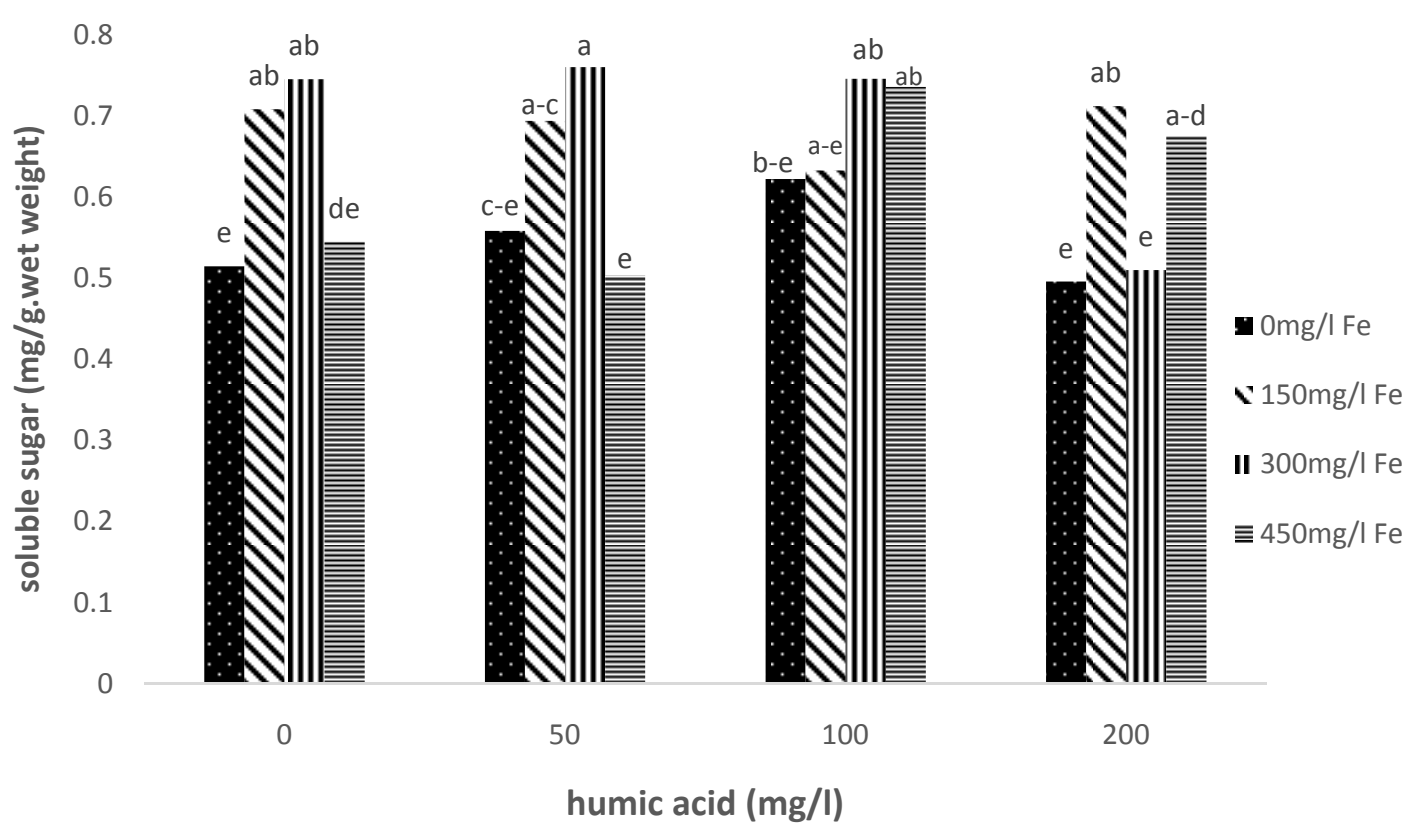

Figure (11): the mutual effects of iron oxide nanoparticles and humic acid application on soluble sugar of snapdragon

\subsection{Electrolyte Leakage:}

Mutual effects of iron oxide nanoparticles and humic acid treatments: the results indicated that the mutual effects of iron oxide nanoparticles and humic acid treatments cause significant differences in terms of electrolyte leakage in such a way that the lowest electrolyte leakage was evidenced for $450 \mathrm{mg} / \mathrm{l}$ iron oxide nanoparticles' treatment (level 4) and $0 \mathrm{mg} / 1$ and $100 \mathrm{mg} / 1$ humic acid treatments (levels $1 \& 3$ ) and the highest electrolyte leakage was obtained for $0 \mathrm{mg} / \mathrm{l}$ iron oxide nanoparticles' treatment (level 1) and 100mg/l humic acid treatment (level 3) (figure 12). The results also demonstrated that the application of humic acid causes significant and positive increase in the cell membrane permeability and reduction in ionic leakage (Dowlatiyan et al, 2013). In another study, the application of humic acid was found decreasing the leakage in beans. Moreover, this organic material has also been found causing significant differences in terms of electrolyte leakage in tomatoes as compared to the evidence treatment. The results of a study indicated that the simple effect of humic acid as well as the mutual effects of salinity and humic acid causes significant differences in terms of electrolyte leakage in contrast to the evidence treatment of the radish plants; it has also been pointed out that the addition of humic acid causes significant increase in electrolyte leakage of the plants in contrast to the evidence treatment. Application of humic acid was found decreasing electrolyte leakage in beans. Electrolyte leakage was also found increased in four rice varieties with the increase in salinity. In tomatoes, the addition of humic acid was not found causing a significant difference in terms of the electrolyte leakage in comparison to the evidence treatment (David et al, 1994). 


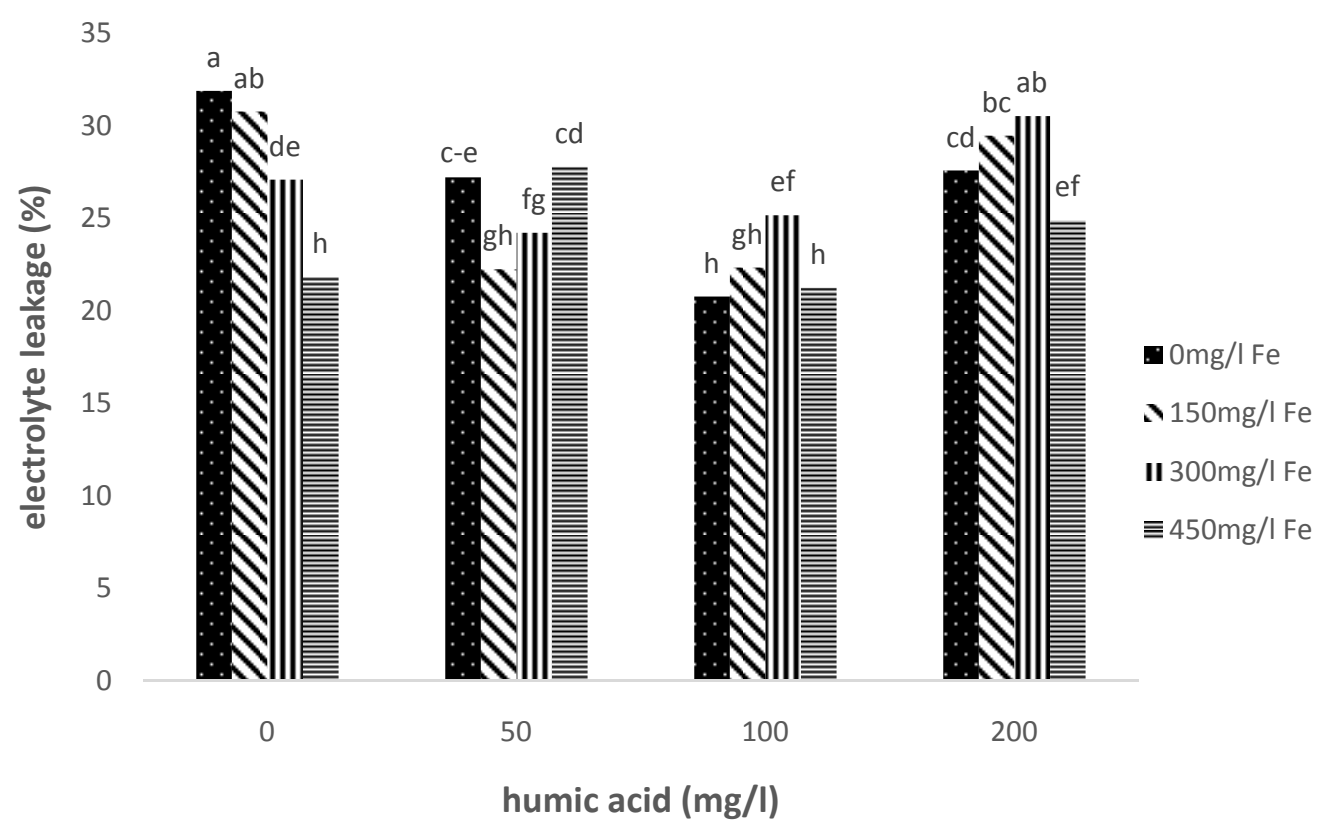

Figure (12): the mutual effects of iron oxide nanoparticles and humic acid applications on electrolyte leakage

\subsection{Anthocyanin:}

The mutual effects of iron oxide nanoparticles and humic acid nanoparticles: the results showed that the mutual effects of iron oxide nanoparticles and humic acid treatments cause significant differences in terms of anthocyanin amount in such a way that the highest anthocyanin amounts were found for $300 \mathrm{mg} / 1$ iron oxide nanoparticles' treatment (level 3) and $0 \mathrm{mg} / \mathrm{l}$ humic acid treatment (level 1) as well as for $150 \mathrm{mg} / \mathrm{l}$ iron oxide nanoparticles' treatment (level 2) and 100 mg/l humic acid treatment (level 3); the lowest amount of anthocyanin was documented for evidence treatment (figure 13). Formation of anthocyanin in plants is usually accompanied by sugar accumulation and any factor causing increase in sugar content of the plants also boosts anthocyanin construction (Dowlatiyan et al, 2013).

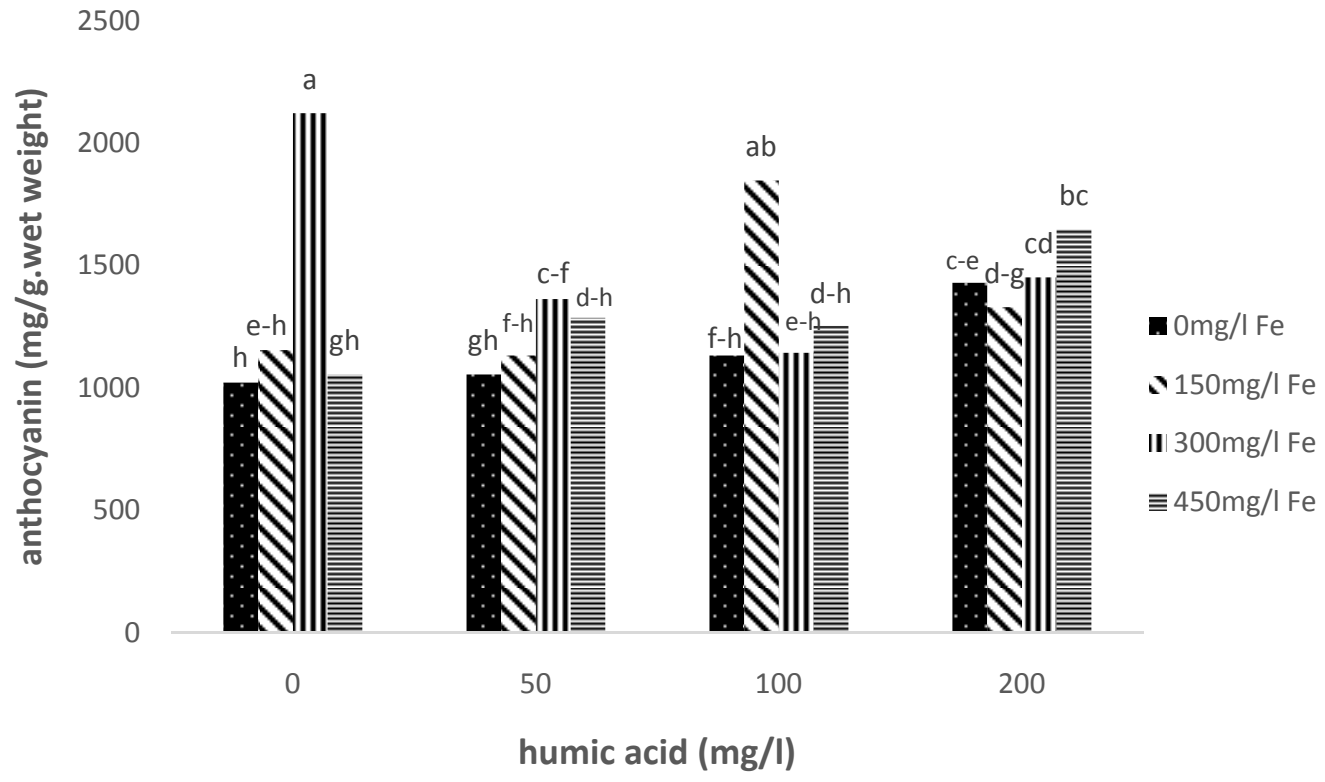

Figure (13): the mutual effects of iron oxide nanoparticles and humic acid applications on anthocyanin in snapdragon 
In this experiment, iron oxide nanoparticles and humic acid treatments were not found with significant effects on such appearance characteristics as number of ancillary branches, number of nodes, plant height, total number of florets, number of open florets, number of close florets and acceleration of second stage flowering (table 1).

\section{General Conclusion:}

Humic acid can directly exert positive effects on plant growth. The aerial parts and root's growth are stimulated by humic acid but its effects are more prominent on the root. It is known that humic acid increases root volume and causes effectiveness of the root system and this is probably a reason for increase in the produced crops.

Humic acid increases absorption of nitrogen, potassium, calcium, magnesium and phosphorus by the plants. Application of humic acid improves the plants' chlorosis which is possibly a result of humic acid's ability in retaining iron in a form that can be absorbed and metabolized. This phenomenon can be more effective in basic and limy soils that usually are poor in absorbable iron and organic materials. Iron is one of the necessary elements for the growth of all plants. In our country, due to the existence of limy soils, plants are less capable of absorbing iron and this causes reduction in the performance of the plants. Nanofertilizers, including iron nanofertilizers, cause readier uptake due to their particles' size and this would have a larger effect on the plants. The results of the study indicated that the treatments have significant effects on some measured traits.

Iron oxide nanoparticles cause improvement in such traits as wet weight of the aerial parts and anthocyanin amount when used in a concentration of $300 \mathrm{mg} / \mathrm{l}$ and it causes an increase in the flowers' persistence and total phenol of the plants when used in a $150 \mathrm{mg} / 1$ concentration. It has also been figured out that $300 \mathrm{mg} / 1$ iron oxide nanoparticles' treatment along with $50 \mathrm{mg} / 1$ humic acid treatment causes an improvement in such traits as dry weight of the aerial parts, chlorophyll $b$ and sugar amount.

Concomitant use of iron oxide nanoparticles for a concentration of $150 \mathrm{mg} / \mathrm{l}$ and humic acid for a concentration of $100 \mathrm{mg} / \mathrm{l}$ brings about the highest increase in the wet and dry weights of root and chlorophyll a content in snapdragon; $450 \mathrm{mg} / \mathrm{l}$ iron oxide nanoparticles and $50 \mathrm{mg} / 1$ humic acid were the most appropriate treatments for having plants with long flower life.

Generally, the results of the present study indicated that the humic acid and iron oxide nanoparticles have positive effects on the majority of the traits; thus, they can be suggested for growing snapdragon. The results indicated that the use of humic acid alongside with iron oxide nanoparticles causes proper growth of snapdragon; considering the organic nature of this material, it will exert no adverse effect on nature and, in the meantime, it is highly contributive to the enhancement of the plant's quality.

According to the present study's findings, it can be stated that the nanofertilizers are preferred to the ordinary fertilizers for their lower volume in spraying efforts as well as for their higher efficiency of application and their greater effects on the quantitative and qualitative traits of seed.

\section{References:}

[1] Afshinmanesh, M.; Ansari, H. and Inanlou, M., (2012), "the effect of applying humic acid and various irrigation regimes on the performance of wheat (Mihan Variety)", MA dissertation, Ferdowsi University, Mashhad

[2] Chamani, A.; Esma'eilpour, B; Pourbeiramihir, Y.; Malaki Lajayer, H. and Sa'adati, A., (2012), "investigating the effect of Thidiazuron and humic acid on the post-harvest life of Alstroemeria flowers, Kinyambe Variety", journal of horticultural sciences (agricultural sciences and industries), 26(2): 147-152

[3] Hosseini Darvishani, S. S. and Chamani A., (2012), "investigating the feasibility of improving he cut flowers of rose, Oled Variety, using some organic treatments and silver thiosulfate", journal of horticultural sciences, (1): 31-41

[4] Daneshvar, M. H., (1993), "floriculture (polycopy)" Ahwaz, Shahid Chamran University Press, p.186

[5] Dowlatiyan, N.; Lakziyan, A.; Fotowwat, A. and Tehranifar, A., (2013), "the effect of humic acid on qualitative and quantitative traits of strawberry, Salvia Variety, under greenhouse conditions", MA dissertation, Ferdowsi University, Mashhad Branch

[6] Rashiditabar, Sh., and Tawhidi, M., (2014), "investigating the effect of humic acid and performance components of corn subject to drought stress under the climatic conditions of northern Khuzestan", the first national conference on Iran's biology and natural sciences

[7] Sabzevari, S.; Khaza'ei, H. R. and Kafi, M., (2009), "the effect of humic acid on the growth of root and aerial parts of wheat (tritticum aestivum L.), Sayonez and Sabalan varieties", journal of water and soil (food sciences and industries), v.23, (2): 87-94

[8] Salehi, B.; Bagherzadeh, A. and Ghasemi, M., (2010), "the effect of organic humic acid materials on the growth, performance and components of performance in three varieties of tomatoes", journal of agricultural ecology, 2(4): 640-647, agency in agricultural sector, Qeshm Island, November, 2013

[9] Fatemi, H.; Ameri, A.; Aminifard, M. H. and Arou'ei, H., (2011), "the effect of humic acid on the essence and growth properties of basil", the first national conference on the novel discussions in agriculture, Saveh, November, 2011, Islamic Azad University

[10] Ghasemi Ghahsareh, M. and Kafi, M., (2005), "scientific and practical floriculture", v.2, p.396

[11] Ghasemi, M.; Kashefi, B and Motallebi, A., (2013), reducing salt stress in ornamental plants using the effect of humic acid", passive defense in agricultural sector, Qeshm Island, November, 2013

[12] Ghorbani, S.; Khaza'ei, H. R. and Sadeghi Shoja'a, M., (2010), "the effect of various levels of humic acid in irrigation water and foliar sprays on the quantitative and qualitative performance of maize fodder (zea mays L.)", passive defense in agricultural sector, Qeshm Island, November, 2013, Teacher Training University Press

[13] Mohammadi, S., (2013), "the effect of zeolite and humic acid on the qualitative traits of miniature roses", passive defense in agricultural sector, Qeshm Island, November, 2013

[14] Malakouti, M. J. and Tehrani, M. M., (1999), "the role of micronutrients in enhancing the performance and improving the quality of agricultural crops", Teacher Training University Press 
[15] Nasirpour, M.; Khoshghalb, H. and Ne'emati S. H., (2014), "investigating the effect of applying humic acid, calcium and boron on the chemical properties and qualitative traits of tomatoes", the second national conference on agricultural engineering and management of the environment and natural sustainable resources, Tehran, March, 2014, Shahid Beheshti University

[16] Arancon, N.Q., Edwards, C.A., Atiyeh, R.M., Metzger, J.D. 2004. Effect of vermicomposts produced from food waste on the growth and yields of greenhouse pepper, Brioresource Technology, 93: 139- 143

[17] Atiyeh, R.M., Lee, S., Edwards, C.A., Arancon, N.Q. and Metzger, J.D., 2002. The influence of humic acids derived from earthwormprocessed organic wastes on plant growth. Bioresource technology, 84(1), pp.7-14

[18] Bailey, L.H., 1949. Manual of cultivated plants: most commonly grown in the continental United Stated and Canada (No. 581.973 B1511m Ej. 1 009043). Macmillan

[19] David, P.P., Nelson, P.V. and Sanders, D.C., 1994. A humic acid improves growth of tomato seedling in solution culture. Journal of plant nutrition, 17(1), pp.173-184

[20] DeRosa, M.C., Monreal, C., Schnitzer, M., Walsh, R. and Sultan, Y., 2010. Nanotechnology in fertilizers, Nature nanotechnology, 5(2), p.91

[21] Gardner, F., Piers, R. and Michelle, L.2011 Physiology of crop plant. Translation: Koocheki and Sarmad Nia Gh: Mashhad SID Press, pp. 372

[22] Gulser, F., Sonmez, F. and Boysan, S., 2010. Effects of calcium nitrate and humic acid on pepper seedling growth under saline condition, Journal of Environmental Biology, 31(5), p.873

[23] Karakurt, Y., Unlu, H., Unlu, H. and Padem, H., 2009. The influence of foliar and soil fertilization of humic acid on yield and quality of pepper. Acta Agriculturae Scandinavica Section B-Soil and Plant Science, 59(3), pp.233-237

[24] Padem, H., Ocal, H.P.A. and Alan, R., 1999. Effect of humic acid added to foliar fertilizer on qualent of eggplant and pepper seedlings. In Proceedings of the International Symposium on Greenhouse Management for Better Yield and Quality in Mild Winter Climates (No.491, p. 241). ISHS

[25] Singh, A.L., Joshi, Y.C., Chaudhari, V. and Zala, P.V., 1990. Effect of different sources of iron and sulfur on leaf chlorosis, nutrient uptake and yield of groundnut. Fertilizer research, 24(2), pp.85-96 